\title{
Characteristics of the Acute Biotoxicity and the Toxic Factors of Tributaries of Baiyangdian Lake
}

\author{
Jie Chen, Meng Wang, Hui Li and Shu-xuan Liang* \\ College of Chemistry and Environmental Science, Hebei University; Key Laboratory of Analytical Science and Technology of Hebei \\ Province, Baoding 071002, China
}

\begin{abstract}
This study aimed to combine the acute biotoxicity test with physic-chemical analysis to pinpoint the toxic factors of river surface water. Water samples were collected from six sampling sites along Fu River, the main tributary of Baiyangdian Lake (China), in the spring and summer of 2018. Acute biotoxicity test was carried using luminous bacteria (Vibrio qinghaiensis sp. Q67) and zebrafish (Brachydanio rerio). The results showed that the river water exerted certain toxic effects on zebrafish and luminous bacteria and the latter was more sensitive to the toxicity of river water; the toxicity to luminous bacteria at the 6 sampling sites was higher in summer than in spring. According to the Pearson correlation coefficient analysis, $\mathrm{COD}, \mathrm{NH}_{3}-\mathrm{N}, \mathrm{Zn}$ and $\mathrm{Cu}$ were the pollution factors that gave rise to the acute toxicity of the surface water and thus should be put under special control.
\end{abstract}

Key words: Acute toxicity, luminous bacteria, zebrafish, toxic factors.

\section{Introduction}

Water quality is crucial to the environmental safety and human health. China is faced with sever water contamination owing to the natural change and human intervention [1]. The water contamination can be well reflected through conventional physic-chemical analysis. Nevertheless, as the pollutants in rivers have toxic effects on aquatic organisms [2], physicochemical indicators alone generally cannot fully reflect the actual toxicity or ecological impact of the pollutants. And the toxicity evaluation alone is unable to show the toxic factors in environment. Hence, one effective way is to evaluate the water quality by combining physicochemical analysis with toxicity assay of organism [3].

Currently, a variety of organisms are used for the acute toxicity assay of water environment [4]. Vibrio qinghaiensis sp. Q67 (referred to as Q67), a kind of freshwater luminous bacteria characterized by quick response, high sensitivity and excellent repeatability, is able to measure the acute toxicity of

Corresponding author: Shu-xuan Liang, Ph.D., professor, research field: environmental chemistry. various water samples effectively [5, 6]. Besides, zebrafish is often used for water toxicity assay for its small size, low feeding cost and high sensitivity to contaminants [7].

As the largest freshwater lake in North China, Baiyangdian Lake lacks natural water supply and mainly depends on tail water of city. Fu River, a tributary of Baiyangdian Lake with the largest water-carrying capacity in the upper reaches, constantly receives municipal sewage and industrial wastewater of Baoding, thereby posing a threat to the ecological environment of Baiyangdian area [8]. Therefore, it is essential to investigate the influences of Fu River on the water quality of Baiyangdian Lake.

In the present study, Vibrio qinghaiensis and zebrafish were used as the experimental species for the acute toxicity test. Six sampling sites were set along Fu River for collecting samples. Subsequently, the acute toxicity and physicochemical indicators were measured in order to evaluate the acute toxicity level of $\mathrm{Fu}$ River water and to pinpoint the material source of biotoxicity, thereby providing basis for the comprehensive assessment on water quality as well as the follow-up environmental governance. 


\section{Material and Methods}

\subsection{Study Area}

The study area is located at the Baiyangdian Basin in Hebei Province. Baiyangdian basin which covers a total area of $31,500 \mathrm{~km}^{2}$ belongs to Daqing River system. Most part of its upstream lies in Baoding City and eventually flows into Baiyangdian Lake whose surface area is $366 \mathrm{~km}^{2}$. The main part of Baiyangdian Lake is situated in Xiongan New Area and is the core of the river system in the area. Xiongan New Area, a national new district established in 2017, holds the philosophy of ecological priority and green development and thus attaches great importance to the water environment of Baiyangdian Lake.

\subsection{Distribution of Sampling Sites and Sample Collection}

$\mathrm{Fu}$ River is the only tributary of Baiyangdian Lake which does not run dry all the year round and receives a large amount of municipal wastewater [8]. Six sampling sites were arranged along $\mathrm{Fu}$ River, among which S1 and S2 were situated on two branches of $\mathrm{Fu}$ River upstream in Baoding City; S3 and S4 lay on the midstream of Fu River; S5 and S6 were located on the downstream section. The locations of the sampling sites are shown in Fig. 1.

The water samples collected $50 \mathrm{~cm}$ below the river surface in April and July 2018 respectively were stored in brown glass bottles and immediately brought back to the lab. Samples were stored in the darkness at $4{ }^{\circ} \mathrm{C}$ until physic-chemical analysis. The toxicity tests were performed on the samples within $48 \mathrm{~h}$ after the collection.

\subsection{Analysis on the Physicochemical Indicators of Water Samples}

pH meter (HQ30d, HACH, USA) and dissolved oxygen meter (HQ30d, HACH, USA) were used to measure the water temperature, $\mathrm{pH}$ and dissolved oxygen in situ. The TN (Total Nitrogen), $\mathrm{NH}_{3}-\mathrm{N}$ (Ammonia Nitrogen), TP (Total Phosphorus) and COD (Chemical Oxygen Demand) in the samples were measured by using a UV-visible intelligent multi-parameter water quality analyzer (LH-3BA, Lianhua Technology, China). The concentrations of heavy metals ( $\mathrm{Al}, \mathrm{Cr}, \mathrm{Ni}, \mathrm{As}, \mathrm{Cd}, \mathrm{Pb}, \mathrm{Cu}$ and $\mathrm{Zn}$ ) were assayed by using ICP-MS (X Series II, Thermofisher, Germany) after being digested with $\mathrm{HCl} / \mathrm{HNO}_{3}$. The ICP-MS operating parameters were as: atomizing gas flow rate of $0.76 \mathrm{~L} / \mathrm{min}$; auxiliary gas flow rate of $0.80 \mathrm{~L} / \mathrm{min}$; ICP RF power of $1,400 \mathrm{~W}$; resolution ( $10 \%$ of peak height) of $0.75 \mathrm{amu}$; dwell time of $30 \mathrm{~ms}$. For quality control and assurance, reagent blanks, standard materials and replicate samples were inserted in the analysis The relative standard deviations of the replicate sample were less than $10 \%$. The recovery rates for the heavy metals ranged from $91.5 \%$ to $110.0 \%$. Each test was triplicated.

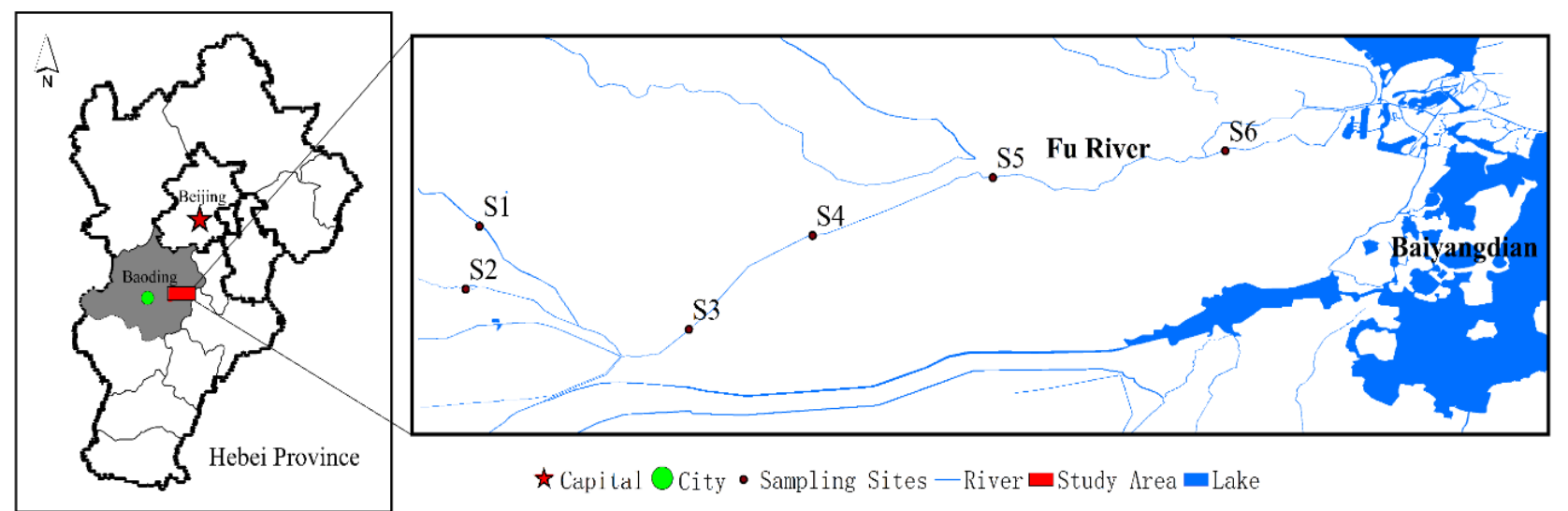

Fig. 1 Distribution of sampling sites along Fu River. 


\subsection{Toxicity Test on Luminous Bacteria}

The Q67 lyophilized powder (obtained from Beijing HAMAMATSU Photon Techniques Inc.) was stored at $-20{ }^{\circ} \mathrm{C}$ and placed at room temperature $\left(20^{\circ} \mathrm{C}\right)$ for 15 min before the test. A suspension of $Q 67$ was made after adding $0.5 \mathrm{~mL}$ of resuscitation diluent at $20{ }^{\circ} \mathrm{C}$. A sample solution to be tested was prepared by mixing the original water sample and an osmotic pressure conditioning solution in 19:1. Then a suspension of Q67 $(0.05 \mathrm{~mL})$ and the prepared sample solution were thoroughly mixed in a test tube. The luminescence intensity was measured by using a quick water toxicity detector (BHP9511, Beijing, HAMAMATSU, China) for 15 min after mixing. Each sample test was triplicated. The acute toxicity is represented by the relative luminescence inhibition rate whose formula is:

$$
\begin{aligned}
& \text { Relative luminescence inhibition rate } \\
& =(1 \\
& \left.-\frac{\text { luminescence intensity of test sample }}{\text { luminescence intensity of control group }}\right) \\
& \times 100 \%
\end{aligned}
$$

\subsection{Acute Toxicity Test on Zebrafish}

Wild type of zebrafish (Brachydanio rerio) for the acute toxicity test was bought from fish-market in Baoding, China, and acclimated in lab for at least 7 days at a water temperature of $25 \pm 1{ }^{\circ} \mathrm{C}$ so as to make sure the mortality is below $5 \%$. Zebrafish with a length of $22 \pm 3 \mathrm{~mm}$ and a weight of $0.2 \pm 0.05 \mathrm{~g}$ were used for tests. The dilution water served as control groups was prepared by referring to standard [9]. Twenty (20) zebrafish were exposed to $4 \mathrm{~L}$ control or sampling water for $96 \mathrm{~h}$ in $5 \mathrm{~L}$ tanks ( $1 \mathrm{~g}$ fish/L water). All assays were performed under the controlled conditions of temperature $\left(25 \pm 1{ }^{\circ} \mathrm{C}\right), \mathrm{pH}(7.4-7.9)$ and $\mathrm{DO}(\geq 80 \%$ saturation). Keep checking the test fishes and note down the abnormal conditions and mortality of the test fishes [10]. Each sample test was triplicated. The acute toxicity for zebrafish is shown through lethality.

\subsection{Statistical Analysis}

The statistical analyses were conducted through SPSS 20.0. One-way ANOVA with Tukey's test was used to analyze the differences $(p<0.05)$. The correlation between the acute toxicity and the physicochemical indices was tested through Pearson correlation coefficient $(p<0.05)$.

\section{Results and Discussions}

\subsection{Toxicity Comparison between Vibrio Qinghaiensis and Zebrafish}

The toxicity test results of water samples are shown in Fig. 2 and 3. The correlation between the relative luminescence inhibition rates and the lethality of zebrafish was analyzed through Pearson correlation coefficient. The results showed that they were significantly and positively correlated, indicating that the acute toxicity of river water can be evaluated through the toxicity tests performed on luminous bacteria and zebrafish. Moreover, the toxicity levels the two kinds of organisms showed are similar and comparable, indicating that the toxic effects of $\mathrm{Fu}$ River water on zebrafish and luminous bacteria are consistent in taxis.

Zebrafish and Q67 were different in their sensibility to water toxicity assay. The relative luminescence inhibition rates of the test samples except for S1 were higher than the corresponding lethality of zebrafish; besides, there were more low toxicity samples detected through Q67 than through zebrafish. Moreover, no obvious acute intoxicating phenomena like inflamed gills and bellies were observed in the dead zebrafish, indicating that the water samples had a slight toxic effect on the zebrafish and the sensitivity of zebrafish to the toxic substances in water samples was low. Therefore, the tests performed on Q67 are more suitable for evaluating the acute toxicity of $\mathrm{Fu}$ River water due to high sensitivity and efficiency. 


\subsection{Toxicity of Water Samples Collected from Fu River}

As shown in Fig. 2, the relative luminescence inhabition rates of $Q 67$ of the six sampling sites in 2018 April and July range within $-5.3 \%( \pm 0.72 \%)-35.72 \%$ $( \pm 3.09 \%)$. Sample S1 produced a stimulatory effect on the luminescence of Q67 both in April and July. The phenomenon can be illustrated by "hormesis-effect", namely, the stimulatory effect of low-concentration toxic chemicals on organismal metabolism [11]. The relative luminescence inhabitation rates of samples at 6 sampling sites were higher in July than in April. Hence, the Fu River water samples collected in July exert a stronger acute toxic effect on Q67. As shown in Fig. 3, the lethality of zebrafish ranges within 0\%-23.33 $( \pm 2.98 \%)$. The four samples, i.e., S1 and S2 in April and S1 and S3 in July, do not cause the death of zebrafish, while the other samples have a significant increase in the fatality rate of zebrafish compared with the control group $(p<0.05)$.

The relative luminescence inhibition rates of $\mathrm{Fu}$ River and Huangpu River (Shanghai) whose water has a low and middle toxicity level are quite close (0-34.6\%) [12]. Nevertheless, the lethality of zebrafish caused by water samples collected from $\mathrm{Fu}$ River is much lower than those caused by the Jiushan River and Shanxia River in Wenzhou (0-100\%) which both are municipal malodorous river [13]. Hence, it is believed that the acute toxicity of $\mathrm{Fu}$ River water is in low and middle level as well.

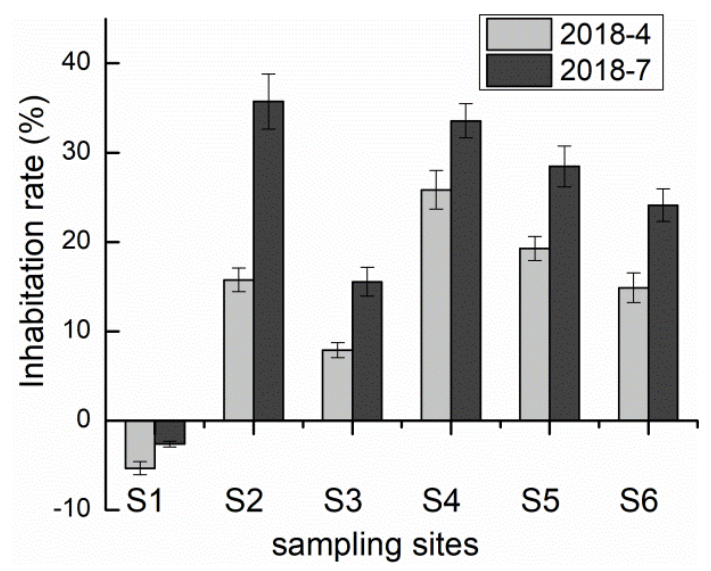

Fig. 2 The relative luminescence inhabitation rates of $Q 67$ of samples.

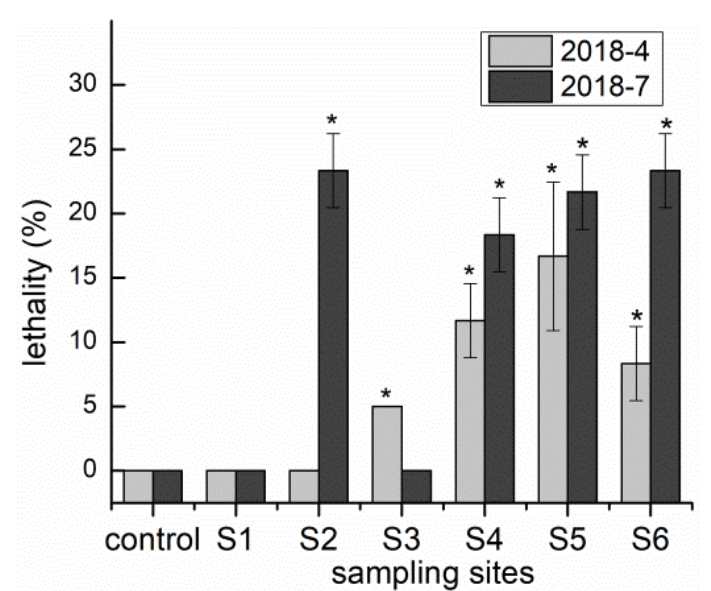

Fig. 3 The lethality of zebrafish of samples.

$*$ indicates significant difference from the control $(p<0.05)$.

\subsection{Physicochemical Characteristics of Water Samples}

The details of the physicochemical indicators of the water samples are presented in Tables 1 and 2. The concentrations of $\mathrm{TN}, \mathrm{NH}_{3}-\mathrm{N}, \mathrm{TP}$ and $\mathrm{COD}$ of most water samples have exceeded the IV Water Quality Limits prescribed in the National Environmental Quality Standards for the Surface Water of China [14]. The $\mathrm{pH}$ values of water samples change greatly neither at different sampling sites nor in different time periods. The water temperatures and the concentrations of $\mathrm{TN}$, $\mathrm{NH}_{3}-\mathrm{N}$ and $\mathrm{COD}$ at the 6 sampling sites were higher in July than in April. In the present study, there are four samples whose DO concentrations are lower than the standard limit ( $3 \mathrm{mg} / \mathrm{L})$. The low DO concentration is possibly caused by the discharge of organic matters and industrial wastes [15]. The reason why the $\mathrm{NH}_{3}-\mathrm{N}$ of sample water fails to reach the IV function planning zone is that the water body has received a large amount of municipal sewage [16]. The TN and TP concentrations of sample water which tower over the internationally recognized critical concentration of water eutrophication (TN $0.2 \mathrm{mg} / \mathrm{L}$ and TP $0.02 \mathrm{mg} / \mathrm{L}$ ) indicate that $\mathrm{Fu}$ River undergoes a severe water eutrophication.

The heavy metal concentrations in the water samples were compared with the CCC (Criterion Continuous Concentration) and CMC (Criterion Maximum Concentration) of the National Recommended Water 
Table 1 Conventional physicochemical indicators at different sampling sites of Fu River in April and July.

\begin{tabular}{lllllllll}
\hline Time & Samples & $\begin{array}{l}\text { Water } \\
\text { temperature }\left({ }^{\circ} \mathrm{C}\right)\end{array}$ & $\mathrm{pH}$ & $\begin{array}{l}\mathrm{DO} \\
(\mathrm{mg} / \mathrm{L})\end{array}$ & $\begin{array}{l}\mathrm{TN} \\
(\mathrm{mg} / \mathrm{L})\end{array}$ & $\begin{array}{l}\mathrm{NH}_{3}-\mathrm{N} \\
(\mathrm{mg} / \mathrm{L})\end{array}$ & $\begin{array}{l}\mathrm{TP} \\
(\mathrm{mg} / \mathrm{L})\end{array}$ & $\begin{array}{l}\mathrm{COD} \\
(\mathrm{mg} / \mathrm{L})\end{array}$ \\
\hline April & S1 & 18.3 & 7.68 & 9.11 & $6.63^{\mathrm{a}}$ & $2.15^{\mathrm{a}}$ & 0.16 & 24.83 \\
& S2 & 16.2 & 7.93 & 7.06 & $5.22^{\mathrm{a}}$ & $2.74^{\mathrm{a}}$ & $0.65^{\mathrm{a}}$ & $33.12^{\mathrm{a}}$ \\
& S3 & 17.2 & 7.73 & 5.04 & $6.11^{\mathrm{a}}$ & $1.86^{\mathrm{a}}$ & $0.32^{\mathrm{a}}$ & $37.40^{\mathrm{a}}$ \\
& S4 & 17.1 & 7.53 & $2.62^{\mathrm{a}}$ & $6.93^{\mathrm{a}}$ & $1.87^{\mathrm{a}}$ & 0.26 & $60.2^{\mathrm{a}}$ \\
& S5 & 16.7 & 7.71 & 4.97 & $8.40^{\mathrm{a}}$ & $3.80^{\mathrm{a}}$ & $0.41^{\mathrm{a}}$ & $42.89^{\mathrm{a}}$ \\
& July & 16.8 & 7.84 & 7.02 & $6.58^{\mathrm{a}}$ & $2.23^{\mathrm{a}}$ & $0.48^{\mathrm{a}}$ & $45.15^{\mathrm{a}}$ \\
& S6 & 31.7 & 7.83 & 9.32 & $14.32^{\mathrm{a}}$ & $3.81^{\mathrm{a}}$ & 0.29 & $40.63^{\mathrm{a}}$ \\
& S2 & 33.1 & 7.70 & $2.31^{\mathrm{a}}$ & $11.92^{\mathrm{a}}$ & $7.38^{\mathrm{a}}$ & $0.76^{\mathrm{a}}$ & $68.48^{\mathrm{a}}$ \\
& S3 & 32.3 & 7.87 & 5.30 & $13.42^{\mathrm{a}}$ & $2.46^{\mathrm{a}}$ & 0.28 & $50.42^{\mathrm{a}}$ \\
& S4 & 32.0 & 8.08 & 7.27 & $12.73^{\mathrm{a}}$ & $3.79^{\mathrm{a}}$ & $0.31^{\mathrm{a}}$ & $73.73^{\mathrm{a}}$ \\
& S5 & 33.6 & 7.88 & $2.53^{\mathrm{a}}$ & $11.22^{\mathrm{a}}$ & $4.68^{\mathrm{a}}$ & $0.71^{\mathrm{a}}$ & $51.17^{\mathrm{a}}$ \\
& S6 & 30.8 & 7.61 & $2.41^{\mathrm{a}}$ & $10.17^{\mathrm{a}}$ & $4.94^{\mathrm{a}}$ & $0.48^{\mathrm{a}}$ & $66.97^{\mathrm{a}}$ \\
\end{tabular}

* represents the IV Water Quality Limit of the National Environmental Quality Standards for the Surface Water of China [14]; indicator with ${ }^{\text {a }}$ means that its value exceeds the IV Water Quality Limit of the National Environmental Quality Standards for the Surface Water of China.

Table 2 Metal concentrations at different sampling sites of Fu River in April and July (unit: $\mu \mathrm{g} / \mathrm{L}$ ).

\begin{tabular}{llllllllll}
\hline Time & Samples & $\mathrm{Al}$ & $\mathrm{Cr}$ & $\mathrm{Ni}$ & $\mathrm{As}$ & $\mathrm{Cd}$ & $\mathrm{Pb}$ & $\mathrm{Cu}$ & $\mathrm{Zn}$ \\
\hline April & S1 & 41.55 & 9.96 & 5.29 & 2.01 & 0.15 & $8.09^{\mathrm{b}}$ & 3.7 & 54.88 \\
& S2 & $195.48^{\mathrm{b}}$ & 11.31 & 10.51 & 5.50 & $0.37^{\mathrm{b}}$ & $19.36^{\mathrm{b}}$ & $14.76^{\mathrm{ab}}$ & $170.71^{\mathrm{ab}}$ \\
& S3 & 35.18 & 11.02 & 7.65 & 1.11 & 0.18 & $9.98^{\mathrm{b}}$ & 4.17 & 86.56 \\
& S4 & 54.85 & 16.45 & 6.08 & 2.84 & 0.14 & $7.98^{\mathrm{b}}$ & $10.32^{\mathrm{b}}$ & 104.27 \\
& S5 & 49.40 & 22.48 & 6.12 & 3.15 & 0.17 & $6.24^{\mathrm{b}}$ & 5.20 & 87.61 \\
& July & $95.00^{\mathrm{b}}$ & 13.11 & 5.22 & 3.08 & 0.24 & $9.63^{\mathrm{b}}$ & 8.47 & 82.23 \\
& S1 & 74.48 & 15.75 & 5.91 & 7.25 & 0.19 & $12.27^{\mathrm{b}}$ & 5.05 & $123.78^{\mathrm{ab}}$ \\
& S2 & $275.76^{\mathrm{b}}$ & 20.79 & 11.54 & 4.54 & $0.44^{\mathrm{b}}$ & $12.95^{\mathrm{b}}$ & $15.19^{\mathrm{ab}}$ & $220.53^{\mathrm{ab}}$ \\
& S3 & 63.37 & 14.19 & 6.26 & 2.41 & 0.16 & $10.09^{\mathrm{b}}$ & 8.80 & 112.96 \\
& S4 & $84.04^{\mathrm{b}}$ & 15.07 & 7.02 & 3.78 & $0.27^{\mathrm{b}}$ & $9.50^{\mathrm{b}}$ & $12.96^{\mathrm{b}}$ & $159.24^{\mathrm{ab}}$ \\
& S5 & $92.76^{\mathrm{b}}$ & 13.91 & 6.72 & 3.55 & 0.24 & $7.07^{\mathrm{b}}$ & 7.55 & $130.41^{\mathrm{ab}}$ \\
& S6 & $157.00^{\mathrm{b}}$ & 15.56 & 5.44 & 3.94 & $0.28^{\mathrm{b}}$ & $11.28^{\mathrm{b}}$ & $20.21^{\mathrm{ab}}$ & $160.93^{\mathrm{ab}}$
\end{tabular}

${ }^{\mathrm{a}}$ means that its value exceeds the $\mathrm{CMC}$ and ${ }^{\mathrm{b}}$ means that its value exceeds the CCC. CMC: the criterion maximum concentration of the National Recommended Water Quality Criteria [17], representing acute exposure. CCC: the criterion continuous concentration of the National Recommended Water Quality Criteria [17], representing chronic exposure.

Quality Criteria [17] respectively. The results showed that the concentrations of $\mathrm{Al}, \mathrm{Cd}, \mathrm{Pb}$ and $\mathrm{Cu}$ of several sampling sites exceeded the CCC and the concentrations of $\mathrm{Cu}$ and $\mathrm{Zn}$ of a few sampling sites surpassed the $\mathrm{CMC}$. It suggests that $\mathrm{Al}, \mathrm{Pb}, \mathrm{Cu}$ and $\mathrm{Zn}$ are the main heavy metal contaminants of Fu River and may have acute toxic effects on the aquatic organisms in the river.

\subsection{Correlation between Toxicity Indices and Physicochemical Indicators}

Heavy metals and organic matters both have acute toxic effects on Q67 [18]. It is found through the Pearson correlation coefficient analysis that the relative luminescence inhibition rate of $Q 67$ is significantly and positively correlated with COD $(r=0.849 ; p<0.01)$, $\mathrm{Zn}(r=0.660 ; p<0.05)$ and $\mathrm{Cu}(r=0.645 ; p<0.05)$ 
(Fig. 4). This indicates the presence of toxic organic pollutants in the $\mathrm{Fu}$ River. The light emitted by luminous bacteria reflects the metabolic status. It is inhibited due to the influence of the toxic organic pollutants on the bioluminescent enzyme system, and there might be the toxicity interaction of the organic pollutants to the luminous bacteria, such as antagonistic, synergistic [19]. The previous researches have proved that $Q 67$ can be used to evaluate the toxicity of river caused by heavy metal pollution [20]. $\mathrm{Wu}$, et al. [5] found that the luminescence inhabitation rates of Q67 of urban highway runoff samples were significantly correlated with heavy metals $\mathrm{Zn}, \mathrm{Fe}$ and Mn and pointed out that heavy metals could inhibit the activity of the flavin mononucleotide in organisms (which is crucially important for the luminous reaction of organisms), thus leading to the luminescence inhibition.

Meanwhile, $\mathrm{COD}$ and $\mathrm{NH}_{3}$ are also significantly and positively correlated with the lethality of zebrafish
(Fig. 5), and the correlation coefficients are 0.766 ( $p<$ $0.01)$ and $0.722(p<0.01)$, respectively. It has been reported that the organic pollutants in environment will have numerous adverse effects on zebrafish [21, 22]. COD is one of the inducements to cause zebrafish death as it reflects the contamination degree of the organic maters in sample water. Besides, $\mathrm{NH}_{3}-\mathrm{N}$ also does great harm to zebrafish [23], because $\mathrm{NH}_{3}-\mathrm{N}$ can easily go into the cell membranes of aquatic organisms, thereby damaging the gills of aquatic organisms and entering their blood, which consequently leads to the death of aquatic organism for anoxia or intoxication [24].

The statistical analyses on toxicity indices and physicochemical indicators show that $\mathrm{COD}, \mathrm{NH}_{3}-\mathrm{N}$, $\mathrm{Zn}$ and $\mathrm{Cu}$ are the major pollution factors of the acute toxicity of $\mathrm{Fu}$ River water; meanwhile, it is quite necessary to evaluate the contamination status of surface water by combing physicochemical indicator analysis with toxicity test.
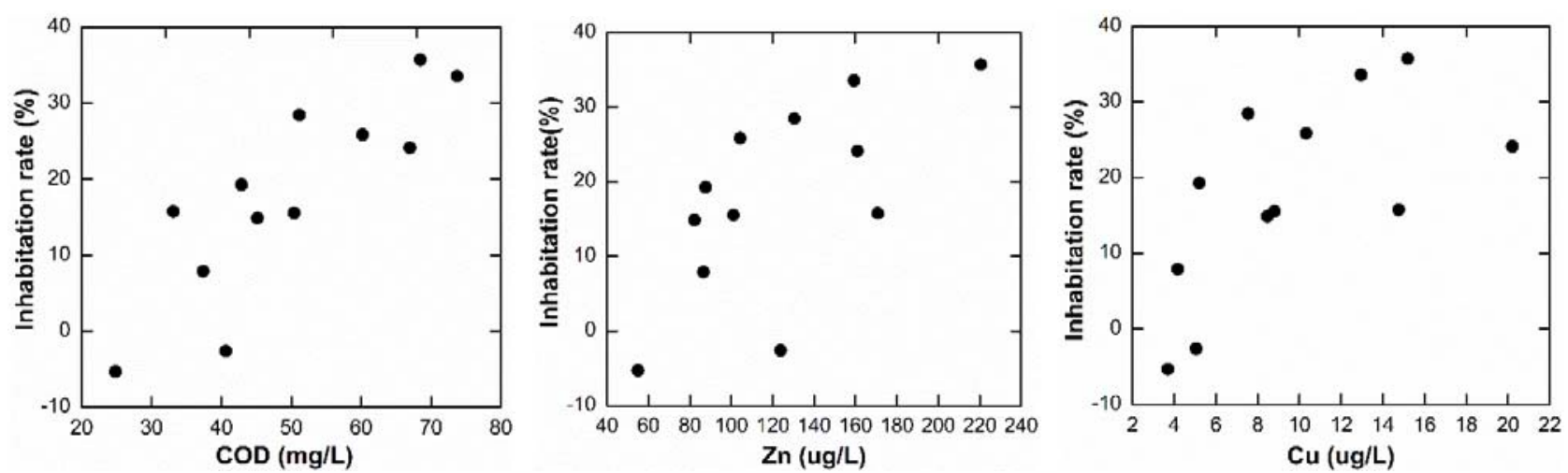

Fig. 4 Correlation between the relative luminescence inhabitation rate of $Q 67$ and physicochemical indicators.
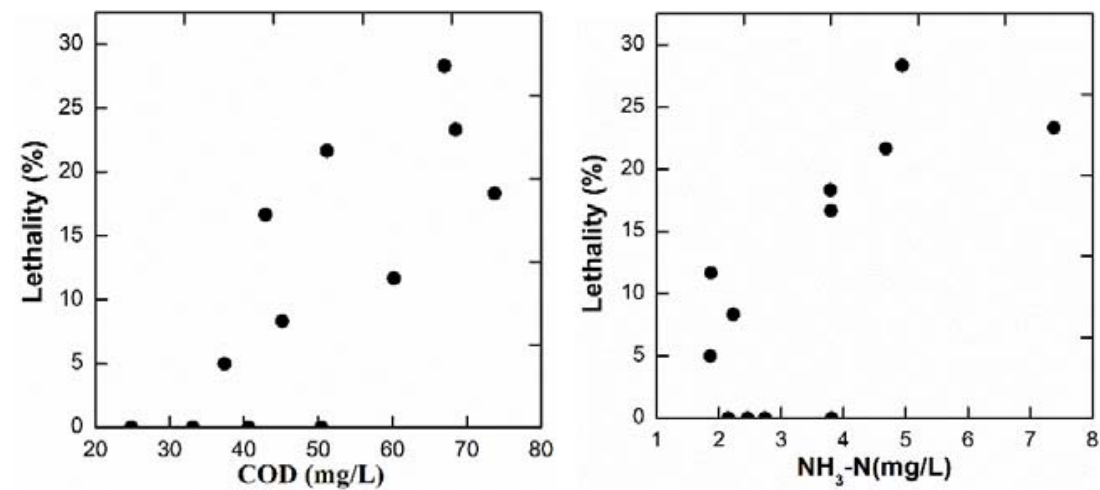

Fig. 5 Correlation between the lethality of zebrafish and physicochemical indicators. 


\section{Conclusion}

This paper evaluated the acute toxicity and physicochemical indicators of Fu River surface water in Baoding City. The comprehensive analysis results showed one rapid and effective way to pinpoint the toxic factors of Fu River water by combining tow acute biotoxicity test (Q67 and Brachydanio rerio) with physicochemical analysis. The water of $\mathrm{Fu}$ River had certain eco-toxic effects on zebrafish as well as luminous bacteria and the toxicity level was low, and the water toxicity was significantly and positively correlated with $\mathrm{COD}, \mathrm{NH}_{3}-\mathrm{N}, \mathrm{Zn}$ and $\mathrm{Cu}$ in the studied water. Therefore, it was suggested to strengthen the control of these pollutants. Furthermore, the water samples collected in July had stronger toxicity. The findings of this study can provide certain basis for the comprehensive assessment on water quality as well as the follow-up environmental governance.

\section{Acknowledgements}

This work was supported by Key Projects of Science and Technology Research in Hebei Higher Education Institutions (ZD2017207), National Natural Science Foundation of China (No. 51708167).

\section{References}

[1] Wang, H., Li, X., and Xie, Y. 2011. "Hydrochemical Evaluation of Surface Water Quality and Pollution Source Apportionment in the Luan River Basin, China." Water Science and Technology 64 (10): 2119-25.

[2] De Castro-Català, N., Kuzmanovic, M., Roig, N., Sierra, J., Ginebreda, A., Barceló, D., et al. 2016. "Ecotoxicity of Sediments in Rivers: Invertebrate Community, Toxicity Bioassays and the Toxic Unit Approach as Complementary Assessment Tools." Science of the Total Environment 540: 297-306.

[3] Chen, R., Li, F., Zhang, H., Jiang, Y., Mao, L., Wu, L., et al. 2016. "Comparative Analysis of Water Quality and Toxicity Assessment Methods for Urban Highway Runoff." Science of the Total Environment 553: 519-23.

[4] Zhao, J. L., Jiang, Y. X., Yan, B., Wei, C., Zhang, L. J., and Ying, G. G. 2014. "Multispecies Acute Toxicity Evaluation of Wastewaters from Different Treatment Stages in a Coking Wastewater-Treatment Plant."
Environmental Toxicology and Chemistry 33 (9): 1967-75.

[5] Wu, L., Jiang, Y., Zhang, L., Chen, L., and Zhang, H. 2014. "Toxicity of Urban Highway Runoff in Shanghai to Zebrafish (Danio rerio) Embryos and Luminous Bacteria (Vibrio qinghaiensis Q67)." Environmental Science and Pollution Research 21 (4): 2663-76.

[6] Ma, K., Qin, Z., Zhao, Z., Zhao, C., and Liang, S. 2016. "Toxicity Evaluation of Wastewater Collected at Different Treatment Stages from a Pharmaceutical Industrial Park Wastewater Treatment Plant." Chemosphere 158: 163-70.

[7] Zhang, W., Liu, W., Zhang, J., Zhao, H., Zhang, Y., Quan, $X$., et al. "Characterisation of Acute Toxicity, Genotoxicity and Oxidative Stress Posed by Textile Effluent on Zebrafish." Journal of Environmental Sciences 24 (11): 2019-27.

[8] Qiu, R., Li, Y., Yang, Z., and Shi, J. 2009. "Influence of Water Quality Change in $\mathrm{Fu}$ River on Wetland Baiyangdian." Frontiers of Earth Science in China 3 (4): 397-401.

[9] The National Standard of the People's Republic of China GB/T13267-91. 1991. The Environmental Protection Agency of China. http://kjs.mee.gov.cn/hjbhbz/bzwb/jcffbz/199208/t19920 801_67269.shtml. (in Chinese)

[10] USEPA EPA-821-R-02-012. 2002. United States Environmental Protection Agency. https://www.epa.gov/ost/criteria/wqctable/.

[11] Shen, K., Shen, C., Lu, Y., Tang, X., Zhang, C., Chen, X., et al. 2009. "Hormesis Response of Marine and Freshwater Luminescent Bacteria to Metal Exposure." Biological Research 42 (2): 183-7.

[12] Zhang, L., Li, Q., Chen, L., Zhang, A., He, J., Wen, Z., et al. 2015. "Toxicity of Surface Water from Huangpu River to Luminous Bacteria (Vibrio qinghaiensis SP. Q67) and Zebrafish (Danio rerio) Embryos." Ecotoxicology and Environmental Safety 112: 137-43.

[13] He, D., Chen, R., Zhu, E., Chen, N., Yang, B., Shi, H., et al. 2015. "Toxicity Bioassays for Water from Black-Odor Rivers in Wenzhou, China." Environmental Science and Pollution Research 22 (3): 1731-41.

[14] The National Standard of the People's Republic of China GB3838-2002. 2002. The Environmental Protection Agency of China. http://kjs.mee.gov.cn/hjbhbz/bzwb/shjbh/shjzlbz/200206/t 20020601_66497.shtml. (in Chinese)

[15] De Castro e Sousa, J. M., Peron, A. P., Da Silva, F. C. C., De Siqueira Dantas, E. B., De Macedo Vieira Lima, A., and De Oliveira, V. A. 2017. "Physico-Chemical and Genotoxicity Analysis of Guaribas River Water in the Northeast Brazil." Chemosphere 177: 334-8. 
[16] Segal-Rozenhaimer, M., Shavit, U., Vengosh, A., Gavrieli, I., Farber, E., Holtzman, R., et al. 2004. "Sources and Transformations of Nitrogen Compounds along the Lower Jordan River." Journal of Environment Quality 33 (4): 1440-51.

[17] USEPA. 2009. "National Recommended Water Quality Criteria." https://www.epa.gov/ost/criteria/wqctable/.

[18] Ma, X., and Wang, X. 2013. "Ecotoxicity Comparison of Organic Contaminants and Heavy Metals Using Vibrio-Qinghaiensis sp.-Q67." Water Science and Technology 67 (10): 2221-7.

[19] Abbas, M., Adil, M., Ehtisham-ul-Haque, S., Munir, B., Yameen, M., Ghaffar, A., et al. 2018. "Vibrio Fischeri Bioluminescence Inhibition Assay for Ecotoxicity Assessment: A Review." Science of the Total Environment 626: 1295-309.

[20] Liu, W., Coveney, R. M., and Chen, J. 2003. "Environmental Quality Assessment on a River System Polluted by Mining Activities.” Applied Geochemistry 18
(5): 749-64.

[21] Zhang, Z., Yu, X., Wang, D., Yan, H., and Liu, X. 2010. "Acute Toxicity to Zebrafish of Two Organophosphates and Four Pyrethroids and Their Binary Mixtures." Pest Management Science 66 (1): 84-9.

[22] Dai, Y., Jia, Y., Chen, N., Bian, W., Li, Q., Ma, Y., Chen, Y., and Pei, D. 2014. "Zebrafish as a Model System to Study Toxicology." Environmental Toxicology and Chemistry 33(1): 11-7.

[23] Zhou, S., Wei, Z., Chu, T., Yu, H., Li, S., Zhang, W., et al. 2018. "Transcriptomic Analysis of Zebrafish (Danio rerio) Embryos to Assess Integrated Biotoxicity of Xitiaoxi River Waters.” Environmental Pollution 242: 42-53.

[24] Ke, X., Bao, Q., Qi, Y., Huang, X., and Zhang, H. 2018. "Toxicity Assessment of Sediments from the Liaohe River Protected Area (China) under the Influence of Ammonia Nitrogen, Heavy Metals and Organic Contaminants." Environmental Toxicology and Pharmacology 59: 34-42. 